IP Periodica Polytechnica

Transportation Engineering

44(3), pp. 187-192, 2016

DOI: $10.3311 /$ PPtr.8809

Creative Commons Attribution (i)

RESEARCH ARTICLE

\section{Inter-Modal Shifts and Sustainability: Call for Freight Transport Privatization in the Indian Railways}

\author{
Prithvi Simha $a^{1,2^{*}}$
}

Received 15 November 2015; accepted 08 February 2016

\begin{abstract}
Given the inherent limitations of state-financed infrastructural development, it is unrealistic to keep looking towards the government in emerging economies to fund the much needed restructuring of their transportation segment. With the Indian Railways facing an unchecked decline in freight transport mix, this study examines the politically romanticized 'public good' nature of Indian Railways to elaborate the need for a modal shift in policy for achieving sustainable transportation. Based on the analysis of historic data, the projected modal split in freight transport is modelled through two scenarios. The business as usual scenario indicated continued preference by the industry for road-based cargo movement. Although the government's National Transport Development Policy Committee calls for increased investment in rail infrastructure and technologies to reach the targeted modal split of 50:50 by 2030 it fails to elaborate where, and who, will finance this venture. This communication thus calls for the privatization of the Indian rail-freight shipment through vertical integration and sub-networks creation. Arguments are supported by scrutinizing past inter-modal shifts in demographically similar Latin American countries.
\end{abstract}

\section{Keywords}

sustainable transportation, Indian Railways, modal shifts, transportation mix, privatization

\footnotetext{
${ }^{1}$ Department of Environmental Sciences and Policy, Central European University, Nádor u. 9, 1051 Budapest, Hungary

${ }^{2}$ School of Earth, Atmospheric and Environmental Sciences (SEAES), The University of Manchester, Oxford Road, Manchester, M13 9PL, United Kingdom
}

Researcher ID: H-2047-2014

*Corresponding author, e-mail: prithvisimha092@gmail.com

\section{Introduction}

In emerging economies like India, traditionally, infrastructure financing been provided by the State. However, this model of finance has its limitations as attested by the substantial infrastructure deficit in these countries as well as growing inability of the State to provide steady investment budgets (Kessides, 2004). With international debt payment and fiscal stress revealing the budgetary vulnerabilities of the State, it would be unrealistic to keep looking towards it for funding infrastructure projects (Lakshmanan, 2008; Koryagin Katargin, 2016). This is especially true considering the scale of additional investment that is required to overcome such deficits.

In this context, the provision of efficient, reliable and safe transportation assumes additional significance for a country like India where historically, the demand has by far, outpaced the supply (Pucher et al., 2004). Given the diversity in location of the markets and resources across the country, the logistical challenges for this sector are substantial. Roadways and Railways dominate the Indian transportation picture in freight movement, where they account for $87 \%$ of the total share as of 2007-2008 (Planning Commission, 2013).

However, over the years, the road-rail mix in freight transport has developed sub-optimally; railways have witnessed a consistent and unchecked decline in their share of the transportation mix to roadways (Brnjac et al., 2010). Unlike roads which developed rapidly on the backdrop of targeted joint public-private investment and governmental policies, railways have failed to respond to market push-pull factors and increase both, their installed capacity to handle cargo and improve technological efficiency.

This communication seeks to examine the 'public good' nature of Indian railways to elaborate the need for a modal shift in transportation policy through an analysis of freight shipment. Past trends of this sector have been mapped and future projections made based on two scenarios. In the context of sustainability, this paper calls for a modal shift to rail-based freight transport via privatization. In order to support this argument, demographically similar countries, Brazil and Argentina were 
analysed as case studies to understand the feasibility as well as efficacy of involving private actors in the transportation arena.

\section{Root causes and call for changes in status-quo}

On an average, the Indian Railways carries through 19000 daily trains, 23 million passengers and 2.65 million tonnes of freight (Ramanathan, 2004). Its network provides employment to nearly 1.6 million people (Bogart and Chaudhary, 2012). Despite these mammoth figures, overutilization of the design capacity is usual practice as the state-run railways has struggled to keep pace with the rising passenger demands, freight traffic and economic aspirations.

The Indian affair with its railways has been highly romanticized by its politicians over the years especially in depicting how it touches the lives of almost every citizen in one way or the other. As is the case in many other developing nations with excessive population but rapidly growing economies, this affair has taken the shape of tax-payer money fuelled subsidies as a means for fulfilling social obligations. Raghuram and Gangwar (2009) elucidate this by demonstrating that $60 \%$ of the Indian Railways transport effort is accounted by passenger transport even though freight operations attribute nearly $70 \%$ of its income. The Indian political ideology has always seen transportation, especially railways, as a "public good" giving it a monopolistic control while regulating passenger and freight tariff costs. The Railways have always lacked investment as massive amounts of tax-payer money had to be rechannelled back as subsidies to ensure affordability of rail transport to the 'common man'.

However, these measures although introduced to initiate economic development and propagate growth, have taken a toll on the system's revenue. With more than $90 \%$ of the generated income spent on social commitments and operating costs, there is little left over for investing into infrastructure improvements (Nanjundappa, 1998). To exemplify this, let's consider the case of railway bridges; nearly a fourth of the 130,000 odd bridges in the country are more than a century old. Hence, when it comes to investment in the railways, it isn't simply about augmenting capacity but also about reducing risks and increasing systemic efficiency.

Furthermore, the Indian economy too has also taken a hit in lieu of its ailing railway system. Freight charges nearly twice of that in China have caused a modal shift with the manufacturing sector being served primarily by roadways (Pucher et al., 2007). An inability to stick to a time frame for shipment of goods is also evident; with cargo and passenger trains sharing the same railway lines, priority has always been given to passenger traffic movement. Delays in the network can be attributed to an aging rail network plagued by the lack of efficient technologies and in dire need of modernization.

\section{Sustainability through Modal Shifts}

The modal shift in transportation from road to a predominantly rail-based system offers a potential pathway to reduce environmental externalities. As shown by Spielmann and Scholz (2005) through an inter-modal Life Cycle Analysis (LCA), railways score much better than road transport when considering a range of factors. In their cradle-to-grave analysis which also accounts for infrastructure requirements, the authors conclude that rail cargo movement allows for a $92 \%$ reduction in gaseous emissions, lowers $\mathrm{PM}_{2.5}$ emissions by $87 \%$, and has negligible heavy metal leakage when compared with roads. In terms of total emissions, road transport has significantly higher cumulative emissions than railways (10\% of total road transport) and water transport (20\% of total road transport) (Spielmann and Scholz, 2005). Moreover the LCA offers another significant insight; it shows that the environmental externalities during transport are highly sensitive to two factors: technology and infrastructure.

Following economic liberalization in the early 1990s, the number of road vehicles in India has grown by more than $90 \%$ (Dargay et al., 2007). An assessment of air pollution inventories indicates that road transport accounts for $94.5 \%$ of these emissions; contrarily, railways have been highly efficient with a meagre $2 \%$ of $\mathrm{CO}_{2}$ and $1.2 \%$ of $\mathrm{CO}$ emissions (Ramachandra, 2009). In contemporary India, the transportation segment consumes $\sim 17 \%$ of the total energy (217 MTOE in 2005-2006) primarily fuelled by fossil- imports that pose a significant burden on the region's climate as well as its foreign exchange flow. This necessitates an examination into the current mobility model.

\section{Modelling transportation trends and projections}

As seen in Fig. 1, following trade liberalization and opening up of the Indian economy in the early-1990s, the increase in the Ton-Kilometres (TKM) for rail transport has been relatively marginal and insignificant when compared to the growth in the 70 s. Figure 2 depicts the historic modal shift in transportation as roadways progressively became the preferred choice.

Through parametric regression with appropriate functional models, these trends were extrapolated to the year 2030 to represent the Business as Usual (BaU) scenario. As per $\mathrm{BaU}$, if current trends continue, ceteris paribus, by 2030 a continued preference by the industry for road-based cargo movement is evident. An alternative to the $\mathrm{BaU}$ has been offered by the National Transport Development Policy Committee (NTDPC), a Government of India enterprise set up in 2010 to develop an integrated transport policy for the country (Mohan and Kapur, 2015).

The NTDPC advocates that by the time India adopts its $15^{\text {th }}$ five-year plan (in 2031) the modal split must reach 50:50 between road and rail (See Fig. 3). As also stated in this study, the Committee assumes that over the coming years governmental policies will tilt transportation strategy in favour of railways. However, reiterating the salient aspect of this argument, 
this shift would entail substantial expansion of rail freight capacity and technological modernization. Moreover, to turn this around, improving capacity utilization alone will not suffice and will undoubtedly necessitate substantial financial outlays for infrastructure development.

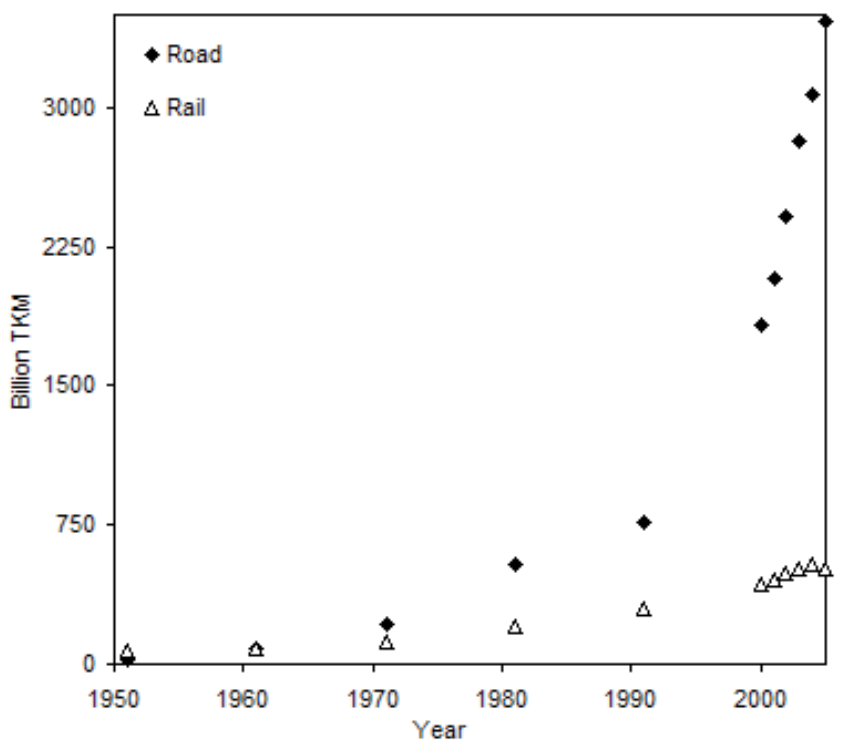

Fig. 1 Historic Trends in Rail and Road Transport in India (in Billion Ton Kilometers); Illustration made by the author with data sourced from Planning Commission (2013) and NTDPC (2011)

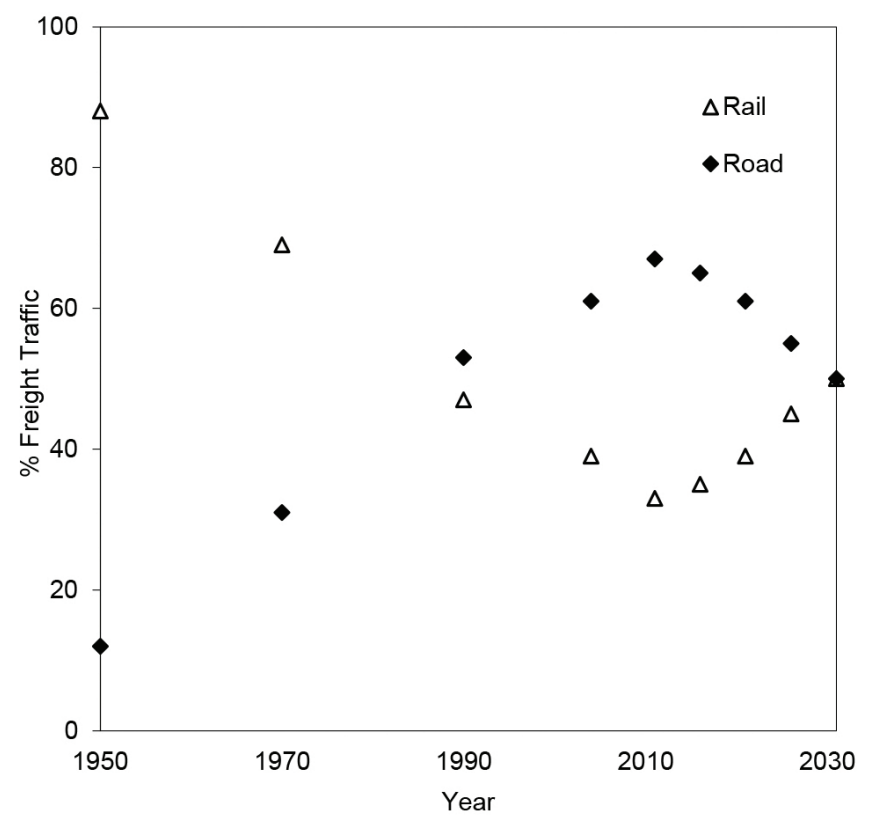

Fig. 2 Historic trends and BaU projection in rail and road freight transport; Illustration made by the author with data sourced from Planning Commission (2013)

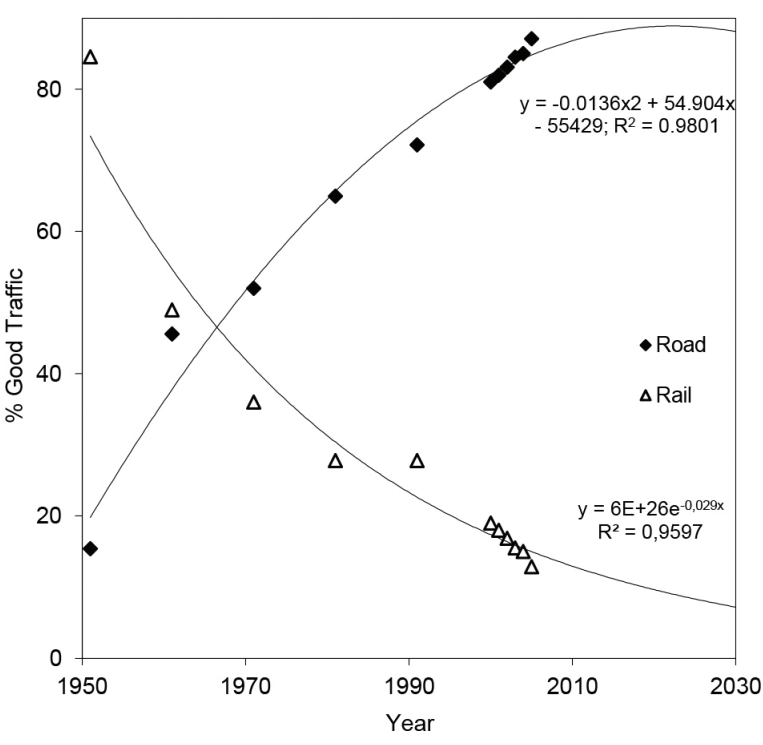

Fig. 3 NTDPC projection for 2030 in rail and road freight transport Illustration made by the author with data sourced from NTDPC (2011)

\section{The General Theory of Privatization}

In order to analyze the feasibility of incorporating private actors into the Indian Railways, it is necessary to interpret on the fundamentals of privatization theory. There are three approaches to privatization of public enterprises:

a. Sale of an existing government-owned entities

b. Private provision of infrastructure or private financing

c. Outsourcing or contracting private vendors for public services.

Privatization is usually accompanied by regulations (to check against monopolistic behavior), deregulations (to allow market equilibrium to establish prices) and/or policy packages (say, intentional monopolization as in the case of British Airways) (Suleiman, 1990; Gomez-Ibanez and Meyer, 1993). Each approach stems from certain motivations on part of the government. While it wouldn't be correct to make generalizations, it also wouldn't be entirely false to comment that private enterprises, with profitability of their investment in mind, would inherently be more efficient that state-owned ones. Certainly, they are inclined to be more cost conscious and customer-oriented. Any gains in efficiency if realized, would eventually translate into reduction of the cost burden of the erstwhile public-owned company on the taxpayers. On the infrastructure front, privatization channels fresh investment into the creation of public services without placing overt liability on the taxman. This is particularly appealing when the public sector is unable to sustain its financial liquidity or expeditiously fund a critically needed infrastructure (Lakshmanan, 2008). Moreover, outsourcing some public services comes with the prospect of immediate financial gains or recovery of initial investment. 


\section{Case Studies and Best Practices}

The transportation segment has always been a focal point for experimentation of the nationalization-privatization cycle. In this section, I seek to summarize the process of incorporating private entities in freight movement through an analysis of the experiences in Brazil and Argentina to assess the applicability of this process. These case study countries were chosen for the purpose of this study as the inherent similarities in the national circumstances of these countries best reflect the current situation in India.

\subsection{Argentina}

Railway reforms in Argentina were driven primarily by the need to reduce fiscal pressure on the national treasury and to revitalize the economy by involving private actors in provisioning of public services. Through the 1989 State Reform and Public Enterprise Restructuring Law, the freight network was partitioned into six sub-networks (earlier operated by the state-owned enterprise Ferrocarriles Argentinos (FA)), each of which was contracted to a private consortium through an openbidding tender process (Estache et al., 1999). Between 1990 and 1993, concessions were granted for a 30-year period with the option for an additional 10-year extension. The nominal criteria for investors was that they had overseas experience in rail operations and had expressed a commitment of investment in infrastructure over the next 15 years; all the auctions were won by Argentinian investors (Carbajo and Estache, 1996). The system was vertically integrated as every private actor was made responsible for all activities in the railroad operations including infrastructural improvements, maintenance, day-to-day movement of trains and financial control. The existing rail infrastructure remained under the ownership of the federal government with private operators paying the government a pre-determined fee for its use. Overall, the government received annual payments amounting to US\$ 140 million and investments of $\sim$ US\$ 1.5 billion were made over a period of 15 years (Campos and Jiménez, 2003). Moreover, $82 \%$ of the former employees of the FA were retained in the sub-network operations. In terms of regulation, although the freight charges were deregulated the operators are required to file the maximum fares for approval by the Secretary of Transport.

As for the performance of the railroads following privatization, freight shipments have more than doubled since the days of the FA. Moreover, for shippers, transportation costs have reduced substantially (a reasonable estimate is over US\$ 70 million annually) on account of improvement in labor productivity from 0.1 to 2 Mtons per worker and in locomotive availability from $50 \%$ to $80 \%$ (Estache et al., 1999).

\subsection{Brazil}

Prior to privatization, the Brazilian railways were operated by public-owned entities, Rede Ferroviária Federal, Sociedade
Anônima (RFFSA), Ferrovia Paulista S.A. (Fepasa), and Companhia Vale de Rio Doce (CVRD). The railway restructuring reforms in Brazil emanated as a response to the poor functioning of the public enterprises which were overstaffed and lacked the investment that was needed to revitalize the existing infrastructure. Moreover, poor revenue to cost ratio necessitated substantial governmental subsidies from public funds. For instance, in the case of RFFSA, employee wages attributed to $75 \%$ of the operating costs and debt burden of $\sim$ US\$ 3 billion (Estache et al., 2001). In 1997, the government decided to vertically integrate the rail network into six monopolies concessioned for a period of 30 years (renewable for another 30 ). The process was initiated through an auction with bids awarded to the consortia offering the highest price relative to the minimum price set by the government. The innovation in the rail reform in Brazil was that the contracts here set out two specifications; (i) output - minimum annual TKMs and (ii) safety - maximum number of accidents per train-kilometer during first five years of operation (Campos, 2001).

Overall, the rail freight's performance in Brazil gradually improved with time. Rail's share in freight shipment increased to $13 \%$ from its erstwhile $4.5 \%$ in 1997 . Moreover, operating subsidies reduced to reflect a net saving of US\$ 300 million annually to the Federal Treasury. Despite increasing competition from road and waterways, the operators were able to realize better freight revenues since 1991 on the account of improved quality of service (Estache et al., 1999).

\section{Conclusions and Recommendations}

This study evaluated the nature of freight transport in India. Through scenario analyses, it has been shown that freight traffic has been witnessing a sub-optimal road-rail mix with business enterprises predominantly favouring roadways. Under the $\mathrm{BaU}$ scenario, this trend is expected to continue; however, a modal shift in policy as advocated by the NTDPC (2011) has the potential to reduce dependencies on roadways. Though the NTDPC calls for increased investment in rail infrastructure and technologies to augment this transformation, it fails to elaborate where and who will generate and finance this venture.

The term transportation 'crisis' is more apt when it comes to developing countries like India. Although an emerging economy, the nation is still plagued with budgetary deficiencies at all levels of governance. Hence, it is not surprising to see the Reserve Bank of India advocate Public-Private Partnerships for the Indian Transportation segment as an approach to alleviate the shortages in public funding and increase State financial flexibility in provisioning of services (Lakshmanan, 2008). Though a seemingly ambitious reform, this paper calls for restructuring the Indian Railways by inclusion of private actors in the freight shipment. Privatization has the potential to channel the massive investment needed to upgrade the current infrastructure and initiate a modal shift to favour rail-based transportation. 
As elaborated through the two case studies in Latin America, privatization of rail freight shipment through vertical integration and creation of sub-networks to promote internal competition among actors did yield significant gains in both, output level and efficiency. Moreover, participation of private actors in the transportation mix has the potential to generate regulatory financing for the State that could in theory, be channelled to promote the goals of sustainability in other sub-sectors of transportation and create a feed-in loop. Similarly, a modal shift can promote the goal of reducing environmental externalities, a criterion that would increase in significance down the road for a country the size of India with an already substantial ecological footprint.

As is the case in initiating most reforms, the adoption of such recommendations hinges primarily on the political will and ideologies of the government in place. A formidable opposition to such changes will eventually be seen from automobile and highway lobbies, which, in the past have been very successful in shaping policies to favour expansion of roadways to stimulate economic growth (See Pucher et al., 2004). However, the recently concluded Rail Budget gives room for inclusion of new actors other than the state in providing the finance needed for restructuring the Indian Railways. This shuns away from the legacy of populism and quixotic announcements as has been the past trend and can be seen as a step in the right direction (Balachandran et al., 2015).

Clearly, the 'crisis' in India's transportation has several dimensions to it; hence, the solutions needed to tackle it will need to be aligned accordingly. In this vein, privatization of rail freight transport can be seen as a hopeful first step. As a further recommendation, a similar study could be commissioned to examine the feasibility of privatizing passenger transport. However, this reform, if debated would see more resistance both from political parties as well as the general public who have been averse to such changes in the past.

\section{Acknowledgement}

The author acknowledges the European Commission's Erasmus Mundus and Erasmus + Program (www.mespom. eu) for the present study carried out at the Central European University, Budapest, Hungary. The author also extends heartfelt gratitude to Dr. Zoltán Illés, former Hungarian state Secretary of Environmental Protection, Nature Conservation and Water Management for useful insights and discussion.

\section{References}

Balachandran, M., Karnik, M., Goshal, D. (2015) The verdict on India's railway budget is out: Suresh Prabhu has kept it real. [Online]. Available from: http://qz.com/351439/the-verdict-on-indias-railway-budget-is-out-sureshprabhu-has-kept-it-real/ [Accessed: 10th November 2015]

Brnjac, N., Abramović, B., Maslarić, M. (2010) Forecasting Intermodal Transport Requirements on Corridor X. PROMET - Traffic \& Transportation. 22(4), pp. 303-307. DOI: 10.7307/ptt.v22i4.195
Bogart, D., Chaudhary, L. (2012) Regulation, ownership, and costs: A historical perspective from Indian railways. American Economic Journal: Economic Policy. 4(1), pp. 28-57. DOI: 10.1257/pol.4.1.28

Campos, J. (2001) Lessons from railway reforms in Brazil and Mexico. Transport Policy. 8(2), pp 85-95. DOI: 10.1016/S0967-070X(01)00007-5

Campos, J., Jiménez, J. L. (2003) Evaluating rail reform in Latin America: Competition and investment effects. In: First Conference on Railroad Industry Structure, Competition and Investment, Toulouse, France, Nov. 7-8, 2003

Carbajo, J., Estache, A. (1996) Railway Concessions: Heading down the Right Track in Argentina. World Bank Publications, Geneva. [Online]. Available from: http://hdl.handle.net/10986/11612 [Accessed: 11th November 2015]

Dargay, J., Gately, D., Sommer, M. (2007) Vehicle ownership and income growth, worldwide: 1960-2030. The Energy Journal. 28(4), pp. 143-170. DOI: 10.5547/issn0195-6574-ej-vol28-no4-7

Estache, A., Carbajo, J., De Rus, G. (1999) Argentina's transport privatization and re-regulation: ups and downs of a daring decade-long experience. (Vol. 2249). World Bank Publications, Geneva.

DOI: $10.1596 / 1813-9450-2249$

Estache, A., Goldstein, A., Pittman, R. (2001) Privatization and Regulatory Reform in Brazil: the case of freight railways. Journal of Industry, Competition and Trade. 1(2), pp. 203-235. DOI: 10.1023/A:1012834715715

Gomez-Ibanez, J. A., Meyer, J. R. (1993) Going Private: The international experience with Transport Privatization. Brookings Institution Press, Washington DC.

Koryagin, M., Katargin, V. (2016) Optimization of an urban transport system on the condition of different goals of municipal authorities, operators and passengers. Transport. 31(1), pp. 63-69. DOI: $10.3846 / 16484142.2016 .1125946$

Kessides, I. (2004) Reforming infrastructure, Privatization, regulation, and competition. World Bank Publications, Geneva.

DOI: $10.1596 / 0-8213-5070-6$

Lakshmanan, L. (2008) Public Private Partnership in Indian Infrastructure Development: Issues and Options. Reserve Bank of India Occasional Papers. 29(1), pp. 37-41. [Online]. Available from: https://rbidocs.rbi. org.in/rdocs/Content/PDFs/ppp1.pdf [Accessed: 25th October 2015]

Mohan, R., Kapur, M. (2015) Getting India Back to the Growth Turnpike: What Will It Take? India Review. 14(1), pp. 128-152. DOI: 10.1080/14736489.2015.1001283

Nanjundappa, D. M. (1998) Railway Pricing and Finances in India. In: Readings in Indian Railway Finance. Verma, K. B. (ed.), Academic Foundation, New Delhi.

National Transport Development Policy Committee (NTDPC) (2011) Working Group on Ports and Shipping for the National Transport Development Policy Committee. Transport Research Wing, Ministry of Road Transport \& Highways, Government of India, New Delhi.

Planning Commission (2013) Twelfth Five Year Plan (2012-2017): Faster, More Inclusive and Sustainable Growth. Sage Publications India, New Delhi. [Online]. Available from: http://planningcommission.nic.in/plans/ planrel/fiveyr/welcome.html [Accessed: 25th October 2015]

Pucher, J., Peng, Z. R., Mittal, N., Zhu, Y., Korattyswaroopam, N. (2007) Urban transport trends and policies in China and India: impacts of rapid economic growth. Transport Reviews. 27(4), pp. 379-410. DOI: $10.1080 / 01441640601089988$

Pucher, J., Korattyswaroopam, N., Ittyerah, N. (2004) The crisis of public transport in India: overwhelming needs but limited resources. Journal of Public Transportation. 7, pp. 95-113. DOI: 10.5038/2375-0901.7.3.5 
Raghuram, G., Gangwar, R. (2008) Indian Railways in the Past Twenty Years Issues, Performance and Challenges. Ahmedabad: Indian Institute of Management. [Online]. Available from: http:/www.iimahd.ernet.in/ assets/snippets/workingpaperpdf/2008-07-05Raghuram.pdf [Accessed: 21st October 2015]

Ramachandra, T. V., Shwetmala (2009) Emissions from India's transport sector - Statewise synthesis. Atmospheric Environment. 43(34), pp. 5510-5517. DOI: 10.1016/j.atmosenv.2009.07.015
Spielmann, M., Scholz, R. (2005) Life cycle inventories of transport services: background data for freight transport. The International Journal of Life Cycle Assessment. 10(1), pp. 85-94.

DOI: $10.1065 /$ lca2004.10.181.10

Suleiman, E. (1990) The politics of privatization in Britain and France. In: The political economy of public sector reform. 1, pp. 113-136. 